\title{
FACTORS INVOLVED IN THE MAINTENANCE OF LUTEAL FUNCTION IN THE PSEUDOPREGNANT RAT*
}

\author{
A. A. SHAIKH AND D. P. GILMORE $\dagger$ \\ The Worcester Foundation for Experimental Biology, \\ Shrewsbury, Massachusetts 01545, U.S.A.
}

(Received 29th March 1973)

\begin{abstract}
Summary. Pseudopregnancy (PSP) in the rat was significantly lengthened by a single injection of $20 \mu \mathrm{g} \mathrm{LH}$ or $100 \mu \mathrm{g} \mathrm{FSH}$ on Day 5. Doses of oestradiol ranging from 0.05 to $0.20 \mu \mathrm{g}$, injected at this time, also significantly prolonged PSP, whereas larger amounts did not. Neither the antioestrogen ICI 46474, nor progesterone, given early in PSP shortened its duration, the antioestrogen itself significantly extended PSP. Daily injections of $20 \mu \mathrm{g} \mathrm{LH}$ to pseudopregnant animals, starting on Day 5, maintained luteal function even longer than did the single dose. Hysterectomy of LH-treated animals did not further extend PSP indicating that the uterus was not involved in terminating luteal function in these animals. Oestrone, oestradiol and progesterone were measured on Day 8 of PSP, in the ovarian venous blood collected from animals treated with ICI 46474 or progesterone on Day 3, and from others subjected to hemiovariectomy and either X-irradiation or sham irradiation on that day. These measurements failed to reveal suppression of oestrogen secretion and consequent reduction in the secretion of other steroids due to the treatments. It is suggested that oestrogens may play an important rôle in the maintenance of luteal function during PSP by complementing the luteotrophic action of the gonadotrophins.
\end{abstract}

\section{INTRODUICTION}

An earlier study (Shaikh \& Yoshinaga, 1970) showed that a single injection of $25 \mu \mathrm{g} \mathrm{LH}$ administered either intravenously or intraperitoneally to rats on certain days of pseudopregnancy (PSP) would significantly extend its duration. Daily injections of the same amount of LH, commencing on Day 5 of PSP, prolonged its duration to an average of 27 days. It was suggested that the increase in the duration of PSP was due to potentiation of prolactin by LH. It was further suggested that the potentiation by $\mathrm{LH}$ was indirectly through stimulation of oestrogen secretion.

Bogdanove (1966) was able to preserve functional corpora lutea in the rat for up to 8 weeks by the daily administration of oestrogens and Gilmore \& McDonald (1969) showed that a single injection of $5 \mu \mathrm{g}$ oestradiol to cycling rats at oestrus or on the 1st day of dioestrus would prolong dioestrus for up to 19 days. Other evidence for the rôle of oestrogen in prolonging luteal function has been

* Supported by contract No. CSD/2169 from the U.S. Agency for International Development.

† Present address: Institute of Physiology, The University, Glasgow, Scotland. 
provided by Macdonald, Armstrong \& Greep (1966), who reported that LH stimulates secretion of oestrogen by rat CL, and by A. A. Shaikh (unpublished observation) who has found that an intravenous injection of LH on Day 5 of PSP in the rat increases oestrogen levels in ovarian venous blood.

The experiments reported here were undertaken in an attempt to clarify the mechanism by which the gonadotrophins and oestrogens can act to maintain luteal function in the rat.

\section{MATERIALS AND METHODS}

Charles River Sprague-Dawley strain rats were used in these studies. These rats were maintained on a daily schedule of $12 \mathrm{hr}$ light ( 07.00 to 19.00 hours). Daily vaginal smears were taken, and only those rats showing regular oestrous cycles of 4 or 5 days were used in the experiments. Pseudopregnancy was induced by vaginal cervical vibration on the day of pro-oestrus and oestrus (De Feo, 1966). The last day of vaginal cornification was taken as Day 1 of PSP. (All references in this paper have been reported after correction so as to conform to this method of dating.) The duration of PSP was determined by daily vaginal smears. The last day before an oestrous smear was taken as the last day of PSP. Injections of LH (NIH-LH-S17) and FSH (NIH-FSH-S8) were given intraperitoneally at a concentration of $20 \mu \mathrm{g}$ in $0.2 \mathrm{ml}$ saline. Control PSP rats received saline alone. The antioestrogenic compound ICI 46474 was dissolved in $5 \%$ ethanol in saline to contain $62 \mu \mathrm{g}$ in $0.2 \mathrm{ml}$ and was administered subcutaneously. Oestradiol- $17 \beta$ and progesterone solutions were made up in oil at a concentration of $1 \mu \mathrm{g} / \mathrm{ml}$ and $10 \mathrm{mg} / \mathrm{ml} \mathrm{respectively} \mathrm{and} \mathrm{also} \mathrm{admin-}$ istered subcutaneously.

\section{$X$-irradiation}

The ovaries were $\mathrm{X}$-irradiated by exposing the ovary through a flank incision, the rest of the body being screened with lead. Approximately $350 \mathrm{R} / \mathrm{min}$ were administered over a period of about 13 min resulting in a total dose of $4400 \mathrm{R}$ (Mandl \& Zuckerman, 1956). The rats were maintained under Nembutal anaesthesia during the operation. The non-irradiated ovary was removed soon after X-irradiation. For sham irradiation, the above procedure was repeated, except that the X-ray machine was not turned on.

\section{Blood collection and assay procedure}

The ovarian venous blood collection was made in heparinized rats under Nembutal anaesthesia according to a method described by Shaikh (1972) for hamsters, the cannulation lasting only $15 \mathrm{~min}$. The blood thus collected was centrifuged and the plasma separated and stored at $-20^{\circ} \mathrm{C}$ until required. The concentrations of oestrone $\left(E_{1}\right)$, oestradiol $\left(E_{2}\right)$, progesterone $(P)$ and $17 \alpha$-hydroxyprogesterone $(17 \alpha-\mathrm{OHP})$ were measured in ovarian vein plasma by radioimmunossay (RIA) following separation of the ether extract on celite microcolumns (Shaikh, 1972). The antiserum to $\mathrm{E}_{2}$ (which cross-reacts with $E_{1}$ ) was used to measure $E_{1}$ and $E_{2}$ at a dilution of $I / 50,000$ and $1 / 80,000$, respectively. The antiserum directed against 11-desoxycortisol (which cross- 
reacts with both $\mathrm{P}$ and $17 \alpha-\mathrm{OHP}$ ) was used to measure $\mathrm{P}$ and $17 \alpha$-OHP at a dilution of $1 / 15,000$. The antiserum also exhibits a $35 \%$ cross reaction with desoxycorticosterone and a $1.2 \%$ cross reaction with $20 \alpha$-hydroxyprogesterone. The values for $17 \alpha-\mathrm{OHP}$ reported here may, therefore, be slight overestimates of the true values. The method of RIA used was that developed by Hotchkiss, Atkinson \& Knobil (1971). A detailed description of this method, with minor modifications has been published (Shaikh, 1971, 1972).

\section{EXPERIMENTAL PLAN}

Rats in Groups A, B, C, E, F, G, H, and I were given a single injection of $20 \mu \mathrm{g} \mathrm{LH}$ (NIH-LH-S17), $20 \mu \mathrm{g}$ and $100 \mu \mathrm{g} \mathrm{FSH} \mathrm{(NIH-FSH-S8),} \mathrm{and} \mathrm{0.05} \mu \mathrm{g}$, $0.1 \mu \mathrm{g}, 0.2 \mu \mathrm{g}, 0.3 \mu \mathrm{g}$ and $0.4 \mu \mathrm{g}$ oestradiol, respectively, on Day 5 of PSP. Progesterone, $2 \mathrm{mg}$, was given to rats in Groups J and $\mathrm{K}$ on Days 1, 2 and 3, or Days $1,2,3,4$ and 5, respectively. Animals in Group D were given saline, and those in Group L were given oil alone on Day 5 of PSP.

Rats in Groups $M$ and $N$ received injections of $62 \mu \mathrm{g}$ of the antioestrogenic compound ICI 46474 on Day 3 alone and on Days 3, 4 and 5, respectively.

Animals in Groups $\mathrm{O}$ and $\mathrm{P}$ were hysterectomized. They were checked for regular cycles before induction of PSP. Group-O animals were given daily injections of saline starting on Day 5, whereas those in Group $P$ received daily injections of $20 \mu \mathrm{g}$ LH starting on Day 5. Group Q included intact controls which received daily injections of saline, whereas Group- $R$ rats received daily injections of $20 \mu \mathrm{g} \mathrm{LH}$ starting on Day 5 of PSP. In Group S, the animals received daily injections of $20 \mu \mathrm{g}$ LH starting on Day 5 and on Day 14 they were hysterectomized. Vaginal smears of all the animals were examined daily to determine the length of PSP.

In another experiment, rats were given $2 \mathrm{mg}$ progesterone from Days 1 to 4 of PSP and, on Day 8 of PSP, ovarian venous blood was collected. Likewise, a single injection of $62 \mu \mathrm{g}$ ICI 46474 was given to another group of rats on the morning of Day 3 of PSP and ovarian venous blood was collected on Day 8 of PSP. Control animals received saline from Days 1 to 8 of PSP and ovarian venous blood was collected on Day 8 . Some rats were also ovariectomized and $\mathrm{X}$-irradiated or sham X-irradiated on Day 3 of PSP and ovarian venous blood was collected on Day 8 of PSP.

\section{RESULTS}

Results of the experiments in which duration of PSP was determined after treating the rats with $\mathrm{LH}, \mathrm{FSH}$ and oestrogen and in rats hysterectomized and treated with LH are listed in Table 1. A single injection of $20 \mu \mathrm{g} \mathrm{LH}$ on Day 5 of PSP (Group A) significantly prolonged PSP to 17.7 days. Controls (salinetreated Group Q) had an average PSP duration of 12.8 days. Although $20 \mu \mathrm{g}$ FSH did not significantly lengthen PSP (Group B, mean PSP length 14.2 days), the higher dose of $100 \mu \mathrm{g}$ did significantly lengthen it to 17.5 days (Group $\mathrm{C}$ ).

Oestradiol, at all dose levels increased PSP (Groups E, F, G, H and I), but only those rats treated with the lower doses (Groups E, F and G) showed a significant difference in PSP duration from controls (Group L). 
When $20 \mu \mathrm{g}$ LH was given daily (Group R) starting on Day 5, the PSP duration was further prolonged to 25.8 days. Hysterectomized PSP rats given daily injections of saline commencing on Day 5 (Group 0) had a PSP duration of 23.6 days which was not increased by substitution of $\mathrm{LH}$ for saline (Group P). Animals, in which LH was administered daily from Day 5 of PSP and hysterectomy was performed on Day 14 , had a PSP duration of 25.6 days which was also not significantly different from Group O. Groups J, K, M and N

Table 1. Pseudopregnancy length in rats treated with LH, FSH, oestrogen, the antioestrogenic compound, ICI 46474, and progesterone and in rats hysterectomized and treated with $\mathrm{LH}$

\begin{tabular}{|c|c|c|c|c|c|}
\hline Group & Treatment & $\begin{array}{c}\text { Day of treatment } \\
\text { (i.p. or s.c.) } \dagger\end{array}$ & $\begin{array}{c}\text { No. of } \\
\text { rats/group }\end{array}$ & $\begin{array}{c}\text { Length of } \\
\text { pseudopregnancy } \\
\text { (mean } \pm S . E .) \\
(\text { days })\end{array}$ & $\begin{array}{l}\text { Range } \\
\text { (days) }\end{array}$ \\
\hline $\begin{array}{l}\text { A } \\
\text { B } \\
\text { C } \\
\text { D } \\
\mathbf{E} \\
\mathbf{F} \\
\mathbf{G} \\
\mathbf{H} \\
\mathbf{I} \\
\mathbf{J} \\
\mathbf{K} \\
\\
\mathbf{L} \\
\mathbf{M} \\
\mathbf{N} \\
\mathbf{O}\end{array}$ & $\begin{array}{l}\text { LH } 20 \mu \mathrm{g} \\
\text { FSH } 20 \mu \mathrm{g} \\
\text { FSH } 100 \mu \mathrm{g} \\
\text { Saline } \\
\text { Oestradiol } 0.05 \mu \mathrm{g} \\
\text { Oestradiol } 0.1 \mu \mathrm{g} \\
\text { Oestradiol } 0.2 \mu \mathrm{g} \\
\text { Oestradiol } 0.3 \mu \mathrm{g} \\
\text { Oestradiol } 0.4 \mu \mathrm{g} \\
\text { Progesterone } 2 \mathrm{mg} \\
\text { Progesterone } 2 \mathrm{mg} \\
\text { Vehicle } \\
\text { ICI } 4647462 \mu \mathrm{g} \\
\text { ICI } 4647462 \mu \mathrm{g} \\
\text { Hysterectomized + } \\
\text { saline } \\
\text { Hysterectomized + } \\
\text { LH } 20 \mu \mathrm{g} \\
\text { Saline } \\
\text { LH } 20 \mu \mathrm{g} \\
\text { LH } 20 \mu \mathrm{g} \\
+ \text { hysterectomy }\end{array}$ & $\begin{array}{l}\text { Day } 5 \text { i.p. } \\
\text { Day } 5 \text { i.p. } \\
\text { Day } 5 \text { i.p. } \\
\text { Day } 5 \text { i.p. } \\
\text { Day } 5 \text { s.c. } \\
\text { Day } 5 \text { s.c. } \\
\text { Day } 5 \text { s.c. } \\
\text { Day } 5 \text { s.c. } \\
\text { Day } 5 \text { s.c. } \\
\text { Day 1, Day 2, Day 3, Day } 4 \text { s.c. } \\
\text { Day 1, Day 2, Day 3, Day 4, } \\
\text { Day } 5 \text { s.c. } \\
\text { Day } 5 \text { s.c. } \\
\text { Day } 3 \text { i.p. } \\
\text { Day 3, Day 4, Day } 5 \text { i.p. } \\
\text { Daily administration } \\
\text { (i.p.) commencing Day } 5 \\
\text { Daily administration } \\
\text { (i.p.) commencing Day } 5 \\
\text { Daily administration } \\
\text { (i.p.) commencing Day } 5 \\
\text { Daily administration } \\
\text { Daily administration } \\
\text { (i.p.) commencing Day } 5+ \\
\text { hysterectomy on Day } 14\end{array}$ & $\begin{array}{r}5 \\
5 \\
5 \\
11 \\
6 \\
15 \\
6 \\
6 \\
10 \\
5 \\
6 \\
6 \\
5 \\
5 \\
3 \\
8 \\
7 \\
7 \\
6 \\
5 \\
9\end{array}$ & $\begin{array}{l}17 \cdot 7 * \pm 2.06 \\
14 \cdot 2 \pm 0.73 \\
17 \cdot 5^{*} \pm 0.49 \\
12 \cdot 8 \pm 0.38 \\
15 \cdot 2^{*} \pm 0.65 \\
16 \cdot 0^{*} \pm 0.86 \\
15 \cdot 6^{*} \pm 0.95 \\
15 \cdot 3 \pm 2 \cdot 12 \\
13 \cdot 3 \pm 0.60 \\
13 \cdot 8 \pm 0.86 \\
13 \cdot 6 \pm 0.67 \\
12 \cdot 4 \pm 0.35 \\
19 \cdot 2 * \pm 1 \cdot 11 \\
19 \cdot 0^{*} \pm 1 \cdot 33 \\
23 \cdot 0 \pm 0.80 \\
22 \cdot 7 \pm 1 \cdot 67 \\
12.8 \pm 0.31 \\
25 \cdot 8 \pm 2.40 \\
25 \cdot 6 \pm 2 \cdot 18\end{array}$ & $\begin{array}{l}13 \text { to } 23 \\
13 \text { to } 16 \\
17 \text { to } 19 \\
11 \text { to } 14 \\
13 \text { to } 17 \\
12 \text { to } 24 \\
13 \text { to } 19 \\
8 \text { to } 24 \\
12 \text { to } 18 \\
12 \text { to } 17 \\
11 \text { to } 16 \\
11 \text { to } 14 \\
16 \text { to } 23 \\
18 \text { to } 22 \\
18 \text { to } 25 \\
17 \text { to } 29 \\
12 \text { to } 14 \\
17 \text { to } 31 \\
17 \text { to } 36\end{array}$ \\
\hline
\end{tabular}

Day 1 of pseudopregnancy $=$ last day of vaginal cornification.

* Significantly different from control $(P<0.05)$.

$\dagger$ i.p. $=$ intraperitoneal; s.c. $=$ subcutaneous.

demonstrated the effects of administering progesterone and the antioestrogenic compound ICI 46474. Contrary to expectation, injection of the antioestrogenic compound on Day 3 alone or on Days 3, 4 and 5 significantly extended the duration of PSP to 19.2 and 19.0 days in Groups $M$ and $N$, respectively. Injection of progesterone on Days 1, 2, 3 and 4 (Group J) or Days 1, 2, 3, 4 and 5 (Group $\mathrm{K}$ ), on the other hand, did not have any effect on PSP length.

Concentrations of $\mathrm{E}_{1}, \mathrm{E}_{2}, \mathrm{P}$ and $17 \alpha-\mathrm{OHP}$ in ovarian venous plasma of PSP rats under various treatment regimens are shown in Table 2 . Only the $P$ concentration in rats treated with $3 \mathrm{mg} P$ from Days 1 to 4 of PSP was significantly higher than in the controls. None of the steroid concentrations in the group treated with ICI 46474 was significantly different from the control. Likewise, 
Table 2. Steroid concentrations in ovarian venous plasma of pseudopregnant rats treated with progesterone or ICI 46474 and also in rats which were hemiovariectomized and the remaining ovary was irradiated on Day 3 of pseudopregnancy

\begin{tabular}{|c|c|c|c|c|c|}
\hline \multirow{2}{*}{ Treatment } & \multirow{2}{*}{$\begin{array}{c}\text { No. of } \\
\text { rats/group }\end{array}$} & \multicolumn{4}{|c|}{ Concentration/ml (mean \pm S.E.) } \\
\hline & & $E_{1} \dagger(p g)$ & $E_{2} \dagger(p g)$ & $P \dagger(\mu g)$ & $17 \alpha-O H P \dagger(n g)$ \\
\hline $\begin{array}{l}\text { Control } \\
\text { Progesterone } \\
\text { ICI 46474 } \\
\text { Sham irradiated } \\
\text { X-Irradiated }\end{array}$ & $\begin{array}{l}6 \\
6 \\
5 \\
3 \\
5\end{array}$ & $\begin{array}{r}62 \pm 8 \cdot 0 \\
52 \pm 5 \cdot 4 \\
57 \pm 5 \cdot 7 \\
143 \pm 34 \cdot 0 \\
100 \pm 23 \cdot 0\end{array}$ & $\begin{array}{l}132 \pm 12 \cdot 4 \\
127 \pm 11 \cdot 6 \\
107 \pm 7.9 \\
428 \pm 192 \cdot 8 \\
176 \pm 17.9\end{array}$ & $\begin{array}{l}0.94 \pm 0.26 \\
1.71 * \pm 0.30 \\
1.21 \pm 0.31 \\
1.49 \pm 0.56 \\
1.36 \pm 0.37\end{array}$ & $\begin{array}{r}81 \cdot 2 \pm 20 \cdot 1 \\
111 \cdot 0 \pm 17 \cdot 2 \\
72 \cdot 6 \pm 26 \cdot 5 \\
106 \cdot 6 \pm 55 \cdot 8 \\
97 \cdot 9 \pm 33 \cdot 1\end{array}$ \\
\hline
\end{tabular}

* Significantly different from control $(P<0.05)$.

$\dagger$ For abbreviations, see text.

there was no significant difference in the steroid concentrations between the group which was hemiovariectomized and the remaining ovary was X-irradiated compared to the group which was hemiovariectomized and the remaining ovary was sham-irradiated.

\section{DISGUSSION}

The present findings that a single injection of $20 \mu \mathrm{g} \mathrm{LH}$ on Day 5 of PSP, or daily injections commencing at that time, significantly extend the duration of PSP confirm the earlier report by Shaikh \& Yoshinaga (1970). It seems reasonable to assume that the higher dose level of FSH extends the duration of PSP in the same manner as does LH, i.e. by stimulating oestrogen secretion, in this case possibly by inducing follicular growth. This possibility, however, depends on the assumption that FSH does stimulate oestrogen secretion and that oestrogens do extend the functional life of corpora lutea in PSP. Our experiments would indicate that oestrogens can have this action when administered in low dose levels.

Uchida, Kadowaki \& Miyake (1970) suggested that oestrogen acts indirectly on the ovaries by stimulating the secretion of luteotrophic substances from the pituitary. This was based on their finding that either oestrogen or prolactin given shortly after ovulation prolonged the rise of ovarian progesterone secretion as well as the duration of the dioestrous phase in vaginal smears. In hypophysectomized rats, oestrogen was not effective but prolactin did prolong the increase of progesterone secretion. The action of oestrogen in prolonging the life of the CL in cycling rats, described by Gilmore \& McDonald (1969), apparently differs in pseudopregnant rats as only the lower doses of oestrogen were effective in the present study. Moreover, at the time the CL are functional during PSP, the levels of prolactin and LH, thought to be responsible for maintaining luteal function (Madhwa Raj \& Mougdal, 1970), have been shown by Bishop, Orias, Fawcett, Krulich \& McCann (1971) to be lower than the levels during dioestrus whereas FSH levels are elevated. This observation supports the view that the high FSH levels, together with the lower levels of LH, account for the continued growth of the follicles and the surge of oestrogen on 
Day 4 of PSP. Hashimoto, Henricks, Anderson \& Melampy (1968) have shown that progesterone secretion, which starts on Day 1 of PSP reaches a peak on Day 6 , and this may be responsible for suppression of further follicular growth and production of oestrogen. It thus appears likely that an injection of a small amount of oestrogen or $\mathrm{LH}$ around this time provides an added stimulus to the luteal cells, significantly extending their life.

If the rôle for oestrogen we have suggested is the correct one, it should be possible to block the oestrogen secretion on Day 4 and thus shorten PSP, though our treatment of pseudopregnant rats with ICI 46474 and progesterone with this object in view was not successful. Neither were significant changes discovered in the plasma steroid levels on Day 8 of PSP in the treated animals, apart from the elevation in progesterone content in those animals treated with this hormone on Day 3. It had been expected that plasma oestrogen levels would be elevated and progestin levels lowered if the luteotrophic effect of the oestrogen surge on Day 4 had been blocked. Although the oestrogen surge may after all have been delayed by the antioestrogenic compound, it seems much more likely that ICI 46474 was itself responsible for lengthening PSP.

$\mathrm{X}$-irradiation seemed to prevent the rise in plasma oestrogen induced by hemiovariectomy, but it did not significantly reduce the concentration of oestrogen when compared to that in the intact controls. Recently, A. F. E. Gibbons and M. C. Chang (personal communication) have observed that pregnant rats with one ovary removed and the other X-irradiated on Day 2 have significantly smaller implantations than control rats on Day 9 of pregnancy. When rats similarly treated were examined on Days 14 or 18 of pregnancy, resorbing or resorbed implants were seen. Injections of $0.05 \mu \mathrm{g}$ oestradiol and/or $2 \mathrm{mg}$ progesterone daily from Day 5 of pregnancy to these rats produced normal implants and live fetuses on Day 18. These observations may indicate that some time elapses after X-irradiation before the follicles are destroyed and oestrogen levels drop. It would thus appear that there is no simple way by which one can easily suppress the oestrogen surge on Day 4 of PSP and so prevent the oestrogen-priming of the luteal cells.

Although the duration of PSP in the hysterectomized rats was considerably greater than in intact controls, daily injections of LH failed to lengthen PSP still further. It is likely, therefore, that the uterus plays no part in terminating PSP in LH-treated rats. A possible explanation for the eventual failure of the $\mathrm{CL}$ in these animals could be that the follicles still continue to grow, though at a much slower rate than during a normal PSP. Eventually, they would secrete oestrogen at an increasing rate, as during late pregnancy (Shaikh, 1971) and, thus, indirectly terminate the functional status of the CL, perhaps through the action of prostaglandins. Blatchley, Donovan, Horton \& Poyser (1972) have shown that prostaglandin levels increase in the presence of oestrogen and high levels of prostaglandins have been found by Shaikh \& Saksena (1973) in the uterine and ovarian venous blood and in peripheral blood of the cycling hamster and close to term in the pregnant hamster when oestrogen levels are also high (Shaikh, 1972).

The possibility that oestrogens might be acting by stimulating the release of LH and FSH was not tested. Ying, Fang \& Greep (1971) reported increases in 
LH and FSH and subsequent ovulation in 30-day-old female rats after a single injection of $0.5 \mu \mathrm{g}$ oestradiol benzoate. In the present study, however, doses of oestradiol higher than $0.2 \mu \mathrm{g}$ were ineffective in prolonging PSP, indicating thereby that oestrogen probably was not acting indirectly by stimulation of gonadotrophin secretion and/or subsequent ovulation.

In summary, our results tend to support the direct action of oestrogens in maintaining corpus luteum function, probably by complementing the luteotrophic effect of the gonadotrophins. The findings that during PSP, LH and prolactin levels are very low (Bishop et al., 1971), and that high doses of both LH and prolactin can be luteolytic (Rothchild, 1965; Malven \& Sawyer, 1966; Malven, 1969) lends further support to a direct luteotrophic effect of oestrogen.

\section{ACKNOWLEDGMENTS}

Grateful acknowledgment is made for the skilful technical assistance of Mrs Rose Bartke and Mrs Shamin Shaikh. Thanks are also due to Dr M. G. Chang and Dr M. J. K. Harper for their critical comments and to the Endocrinology Study Section of NIH for providing NIH-LH and NIH-FSH. Antiserum to oestradiol-17 $\beta$ was kindly supplied by Dr Burton Caldwell, Yale University, New Haven, Connecticut. Antiserum to 11-desoxycortisol was kindly supplied by Dr Guy E. Abraham, Harbor General Hospital, Torrance, California.

\section{REFERENCES}

Bishop, W., Orias, R., Fawcett, C. P., Krulich, L. \& McCann, S. M. (1971) Plasma gonadotropins and prolactin in pseudopregnancy in the rat. Proc. Soc. exp. Biol. Med. 137, 1411.

Blatchley, F. R., Donovan, B. T., Horton, E. W. \& Poyser, N. L. (1972) The release of prostaglandins and progestin into the utero-ovarian venous blood of guinea-pigs during the oestrous cycle and following oestrogen treatment. 7. Physiol., Lond. 223, 69.

Bogdanove, E. M. (1966) Preservation of functional corpora lutea in the rat by estrogen treatment. Endocrinology, 79, 1011.

DE FEo, V. J. (1966) Vaginal-cervical vibration: a simple and effective method for the induction of pseudopregnancy in the rat. Endocrinology, 79, 440.

Gilmore, D. P. \& McDonald, P. G. (1969) Induction of prolonged diestrus in the rat by a low level of estrogen. Endocrinology, 85, 946.

Hashimoto, I., Henricks, D. M., Anderson, L. L. \& Melampy, R. M. (1968) Progesterone and pregn4 -en-20 $\alpha$-ol-3-one in ovarian venous blood during various reproductive states in the rat. Endocrinology, 82, 333.

Hotchiss, J., Atкinson, L. E. \& KnobiL, E. (1971) Time course of serum estrogen and luteinizing hormone $(\mathrm{LH})$ concentrations during the menstrual cycle of the rhesus monkey. Endocrinology, $89,177$.

Macdonald, G. J., Armstrong, D. T. \& Greep, R. O. (1966) Stimulation of estrogen secretion from normal rat corpora lutea by luteinizing hormone. Endocrinology, 79, 289.

Madhwa RaJ, H. G. \& Moudgal, N. R. (1970) Hormonal control of gestation in the intact rat. Endocrinology, 86, 874.

Malven, P. V. (1969) Luteotrophic and luteolytic responses to prolactin in hypophysectomized rats. Endocrinology, 84, 1224.

Malven, P. V. \& Sawyer, C. H. (1966) A luteolytic action of prolactin in hypophysectomized rats. Endocrinology, 79, 268.

MAnde, A. M. \& Zuckerman, S. (1956) The reactivity of the X-irradiated ovary of the rat. F. Endocr. $13,243$.

Rothchild, I. (1965) The corpus luteum-hypophysis relationship. Acta endocr., Copenh. 49, 107.

Shaikh, A. A. (1971) Estrone and estradiol levels in the ovarian venous blood from rats during the estrous cycle and pregnancy. Biol. Reprod. 5, 297.

Shaikh, A. A. (1972) Estrone, estradiol, progesterone and 17 $\alpha$-hydroxyprogesterone in the ovarian venous plasma during the estrous cycle of the hamster. Endocrinology, 91, 1136. 
Shaikh, A. A. \& Saksena, S. K. (1973) Cyclic changes in uterine venous and peripheral plasma levels of $\mathrm{F}$ prostaglandins correlated with peripheral progesterone levels in the golden hamster. Adv. Biosci. 9, 835.

Shaikh, A. A. \& Yoshinaga, K. (1970) Prolongation of pseudopregnancy in rats by LH. Biol. Reprod. 3, 31 .

Uchida, K., Kadowaki, M. \& MiYake, T. (1970) Further studies on the effect of exogenous progesterone and related compounds on the preovulatory progesterone secretion in the rat. Endocr. jap. 17, 509.

YING, S. Y., FANG, V. S. \& GreeP, R. O. (1971) Estradiol benzoate (EB)-induced changes in serum luteinizing hormone (LH) and follicle-stimulating hormone (FSH) in immature female rats. Fert. Steril. 22, 799. 